\title{
Role of women in vegetable production in distict Patiala
}

\author{
RACHNA SINGLA AND GURUPDESH KAUR
}

Received: 22.06.2016; Revised: 01.10.2016; Accepted: 16.10.2016

See end of the paper for authors' affiliations RACHNA SINGLA

Krishi Vigyan Kendra, PATIALA (PUNJAB) INDIA

Email : singlarachna77@gmail.com
DABSTRACT : The present study was carried out to find role of women in vegetable production area of Patiala. KVK, Patiala develops technical models for poverty alleviation, sustainable and equitable development and raise the income and quality of people by providing them training in various aspects of agriculture to supplement food and income. This study was conducted in five villages i.e. Khokh, Birarwal, Saholi, Binaheri and Gunike of district Patiala during 2014. Thirty female respondents each of the selected from four villages were interviewed. The results of the personal characteristics showed that majority of respondents were in age group of 20-40 years, 14 per cent of the total respondents were educated, 87 per cent of the respondents were landless labours. Education and adoption of vegetable growing practices were positively correlated. The results further showed that 95 per cent of the respondents engaged in picking of vegetables and 88 per cent invoved in sowing of vegetables at farmer's fields. Major constraints in vegetable production found in the study were lack of capital, credit availability and lack of marketing facilities.

KEY WORDS: Women, Vegetable, Role, Production, Participation, Constraint

- HOW TO CITE THIS PAPER : Singla, Rachna and Kaur, Gurupdesh (2016). Role of women in vegetable production in distict Patiala. Asian J. Home Sci., 11 (2) : 335-340, DOI: 10.15740/HAS/AJHS/ 11.2/335-340. 